Grygorowicz M., Pawlak M. Risk factors for anterior cruciate ligament injury in female football players. Issue Rehabil. Orthop. Neurophysiol. Sport Promot. 2016; 17: 87-104.

\section{RISK FACTORS FOR ANTERIOR CRUCIATE LIGAMENT INJURY IN FEMALE FOOTBALL PLAYERS \\ Monika Grygorowicz ${ }^{1,2}$ \\ Maciej Pawlak ${ }^{2}$}

'Department of Physiotherapy, Stanisław Staszic University of Applied Science in Piła

${ }^{2}$ Rehasport Clinic FIFA Medical Centre of Excellence

\section{SUMMARY}

Women's football is a rapidly growing discipline. In the last 15 years we can observe significantly growing interest in women's football in Poland. However, the growth in the absolute number of players translates into statistical increase of the risk of injury. Many authors confirm that the risk of a serious knee injury is significantly higher in female than in male players. This is particularly true for anterior cruciate ligament (ACL) injuries, which occur from 2.2 to 6-7 times more often among women than men. The paper describes ACL injury factors; those non-modifiable and those, which can be modified by training, and thus the risk of injury might be reduced.

Keywords: anterior cruciate ligament, ACL, injury, risk factors, female football

Date received: October 4th 2016

Date accepted: October 24th 2016

\section{Introduction}

Over the past 15 years there has been growing interest in women's football in Poland. There has been a steady increase in the number of players participating in regular competitions at club level of the first,
CZYNNIKI RYZYKA USZKODZENIA WIĘZADŁA KRZYŻOWEGO PRZEDNIEGO WŚRÓD PIŁKAREK NOŻNYCH

Monika Grygorowicz ${ }^{1,2}$

Maciej Pawlak ${ }^{2}$

1Zakład Fizjoterapii Państwowej Wyższej

Szkoły Zawodowej im. Stanisława Staszica w Pile

${ }^{2}$ Rehasport Clinic FIFA Medical Centre of Excellence

\section{STRESZCZENIE}

Kobieca piłka nożna jest dyscyplina bardzo szybko się rozwijającą. W ciągu ostatnich 15 lat znacząco wzrosło zainteresowanie piłką nożną kobiet w Polsce. Wraz ze wzrostem bezwzględnej liczby zawodniczek wzrasta także statystycznie możliwość odniesienia kontuzji w grupie piłkarek. Wielu autorów potwierdza, iż ryzyko poważnego uszkodzenia stawu kolanowego jest znamiennie wyższe u piłkarek niż u piłkarzy nożnych; w szczególności do urazu więzadła krzyżowego przedniego (ACL) dochodzi od 2,2 do 6-7 razy częściej wśród kobiet niż wśród mężczyzn. W pracy scharakteryzowano czynniki ryzyka uszkodzenia więzadła ACL: te niemodyfikowalne oraz te na które w trakcie treningu można wpływać i tym samym zmniejszać ryzyko pojawienia się kontuzji.

Słowa kluczowe: więzadło krzyżowe przednie, ACL, uszkodzenie, czynniki ryzyka, piłka nożna kobiet

Data otrzymania: 4 października 2016

Data zaakceptowania: 24 października 2016

\section{Wprowadzenie}

Na przestrzeni ostatnich 15 lat zauważa się znaczny wzrost zainteresowania piłką nożną kobiet w Polsce. Coraz więcej zawodniczek uczestniczy w regularnych rozgrywkach klubowych na poziomie ekstraligi, I, II i III 
second and third division, organized by the Polish Football Association and Regional Associations. The youngest girls take part in such tournaments as „Marek Wielgus Orange Cup" or "From the backyard to the stadium - Tymbark Cup". Teenagers compete in national competitions organized within the National Olympic Games for Youth, which is often their first opportunity at winning prizes and medals. On the one hand, the growth in the number of girls and young women actively playing football should be seen as a positive thing: increased competition improves skill level in the discipline. On the other hand, however, the growth in the absolute number of players translates into statistical increase of the risk of injury.

The data revealed by FIFA Medical Committee show that the most common injuries suffered by female players are injuries of the ankle joint, knee, lower extremity in general and the head (Junge and Dvorak 2007; Park et al. 2012). Many authors confirm that the risk of a serious knee injury is significantly higher in female than in male players. This is particularly true for anterior cruciate ligament (ACL) injuries, which occur from 2.2 to 6-7 times more often among women than men (Junge and Dvorak 2007; Waldén et al. 2010; Wordeman et al. 2012). The information about higher risk of injury and greater number of actual injuries in women are corroborated by years of observations, monitoring of collegiate competitions, youth tournaments, and analyses of injuries during international football tournaments played at the highest skill level. Knee injuries are common and they are a serious problem regardless of the player's skill level (Hägglund et al. 2009; Wordeman et al. 2012). They cause long breaks in training, and in some cases such an injury may become the direct cause of leaving the game altogether (Söderman et al. 2002; Beynnon et al. 2014). ACL injury is also ligi, którym patronuje Polski Związek Piłki Nożnej i Związki Regionalne. Najmłodsze dziewczynki biorą udział w turniejach „Orange Cup im. M Wielgusa” czy „Z podwórka na stadion o puchar Tymbarku". Starsze dziewczęta i młodzież rywalizują w krajowych zawodach sportowych w ramach Ogólnopolskiej Olimpiady Młodzieży uzyskując najczęściej w ten sposób swoje pierwsze tytuły i wyróżnienia. Z jednej strony, ta zwiększająca się liczba dziewczynek, dziewcząt i kobiet czynnie uprawiających piłkę nożną powinna cieszyć, ponieważ w myśl zwiększonej rywalizacji - może się zdecydowanie przyczynić do podniesienia poziomu sportowego dyscypliny. Jednak z drugiej strony, wraz ze wzrostem bezwzględnej liczby zawodniczek wzrasta także statystycznie możliwość odniesienia kontuzji w grupie piłkarek.

Dane komisji medycznej FIFA wskazują, iż najczęściej wśród piłkarek kontuzje dotyczą okolicy stawu skokowego, stawu kolanowego, kończyny dolnej oraz głowy (Junge i Dvorak 2007; Park i wsp. 2012). Wielu autorów potwierdza, iż ryzyko poważnego uszkodzenia stawu kolanowego jest znamiennie wyższe u piłkarek niż u piłkarzy nożnych; w szczególności do urazu więzadła krzyżowego przedniego (ACL) dochodzi od 2,2 do 6-7 razy częściej wśród kobiet niż wśród mężczyzn (Junge i Dvorak 2007; Waldén $i$ wsp. 2010; Wordeman $i$ wsp. 2012). Informacje o wyższym ryzyku i wyższej liczbie kontuji wśród piłkarek nożnych w porównaniu do piłkarzy poparte są to wieloletnimi obserwacjami i pochodzą zarówno z monitoringu sportów uniwersyteckich, rozgrywek młodzieżowych, czy analizy urazów na międzynarodowych turniejach piłkarskich rozgrywanych na najwyższym poziomie. Urazy stawu kolanowego sa częste i stanowia poważny problem niezależnie od poziomu zaawansowania zawodniczego (Hägglund $i$ wsp. 2009; Wordeman i wsp. 2012). Skutkują długą przerwą w treningach, a w niektórych przypadkach mogą stać się bezpośrednią 
associated with the increased risk of reinjury of the knee joint (Horton and Hall 1989; Faude et al. 2006), and long-term effects may include reduced physical fitness due to osteoarthritis of the joint (Moeller and Lamb 1997; Lohmander et al. 2004). Risk factors can be divided into non-modifiable and modifiable by training reducing the risk of injury. The two groups of factors are described in detail below.

\section{Aim}

The aim of the study is to characterise in details modifiable and non-modifiable risk factors for the anterior cruciate ligament injury and to underline the difficulty of ACL injury prediction resulting from methodological limitations of applied research.

\section{Modifiable factors of ACL injury risk}

Dominance of the quadriceps femoris muscle

Much is known about neuromuscular control of selected motor activities in men and female players. It has been proved that female players have significantly lower muscle strength and endurance than male players; also, it has been noted that the order of muscle fiber recruitment is different in some female players. It consisted in abnormally increased tension of the quadriceps muscle (the antagonist of ACL) in response to the displacement of the tibia (Huston and Wojtys 1996). It should be noted that incorrect neuromuscular control has been identified as one of the main etiological factors influencing the high frequency of non-contact ACL injuries in women (Griffin et al. 2000). przyczyną rezygnacji z gry (Söderman $i w s p$. 2002; Beynnon $i$ wsp. 2014). Uszkodzenie więzadła ACL wiąże się także ze wzrostem ryzyka ponownej kontuzji stawu kolanowego (Horton i Hall 1989; Faude i wsp. 2006), a odległym w czasie skutkiem takiego uszkodzenia może być ograniczenie sprawności fizycznej związane z chorobą zwyrodnieniową stawu (Moeller i Lamb 1997; Lohmier $i$ wsp. 2004). Czynniki ryzyka można pogrupować na niemodyfikowalne i te, na które w trakcie treningu można wpływać i tym samym zmniejszać ryzyko pojawienia się kontuzji.

\section{Cel}

Celem pracy jest szczegółowa charakterystyka modyfikowalnych i niemodyfikowalnych czynników ryzyka uszkodzenia więzadła krzyżowego przedniego oraz podkreślenie trudności zjawiska predykcji tej kontuzji wynikające z ograniczeń metodologicznych stosowanych badań.

\section{Modyfikowalne czynniki ryzyka uszko- dzenia ACL}

Dominacja mięśniowa mięśnia czworogłowego uda

Wiele wiadomo o sposobie kontroli nerwowo-mięśniowej wybranych czynności ruchowych w grupie zawodniczek i zawodników. Wykazano znacznie mniejszą siłę i wytrzymałość mięśni w grupie zawodniczek w porównaniu do grupy zawodników; odnotowano także odmienną kolejność rekrutacji włókien mięśniowych u niektórych sportsmenek. Polegała ona na nieprawidłowo zwiększonym napięciu mięśnia czworogłowego uda (który jest antagonistą ACL), w odpowiedzi na przesunięcie piszczeli (Huston i Wojtys 1996). Pamiętać należy, że niewłaściwa kontrola nerwowo-mięśniowa została zidentyfikowana jako jeden z głównych czynników etiologicznych wpływający na wysoką częstotliwość bezkontaktowych urazów ACL u kobiet (Griffin $i$ wsp. 2000). 
Lower value of the Hcon / Qcon ratio (muscle imbalance)

One of the factors leading to increased ACL injury risk is imbalance between the quadriceps femoris muscle and the hamstring, and incorrect value of the Hcon/ Qcon ratio (Söderman et al. 2001). Strength balance between these antagonists in crucial for the correct, dynamic stabilization of the knee joint. If the quadriceps femoris muscle is much stronger than the hamstring muscle group, excessive frontal translation may occur during such dynamic actions as landing, rapid change of movement direction, or dribble, resulting in the increased influence of shearing forces on the ACL. If the hamstring muscles are too weak to counteract these forces, the ACL is exposed to a high risk of injury (Bencke and Zebis 2011).

\section{Limb dominance}

Brophy et al. analyzed the role and influence of lower limb dominance on the risk of ACL injury in male and female football players. The retrospective study, conducted on a group of 41 male and 52 female players, showed that more than $50 \%$ of all ACL injuries occurred to the dominant limb (53 injuries of 99 injuries registered in total). The dominant limb suffered an injury in $32.26 \%$ female players and $74.07 \%$ of male players ( $\mathrm{p}<0.002)$ (Brophy et al. 2010). The relation between limb dominance and injury, including the ACL injury, remains unclear and further research is necessary to draw legitimate conclusions concerning female footballers.
Mniejsza wartość wskaźnika Hcon/Qcon (zaburzenia równowagi mięśniowej) Jednym z czynników wpływających na zwiększone ryzyko uszkodzenia więzadła ACL jest także zaburzona równowaga mięśniowa pomiędzy mięśniem czworogłowym uda, a grupą mięśni kulszowo-goleniowych tj. nieprawidłowa wartość wskaźnika Hcon/ Qcon (Söderman $i$ wsp. 2001). Zachowanie właściwej proporcji siłowej tych antagonistów jest konieczne dla prawidłowej dynamicznej stabilizacji stawu kolanowego. W sytuacji gdy mięsień czworogłowy uda jest zdecydowanie silniejszy niż mięśnie grupy kulszowo-goleniowej w trakcie wykonywania dynamicznych czynności takich jak lądowanie, nagła zmiana kierunku ruchu czy zwód może pojawić się nadmierna przednia translacja i może dojść do zwiększenia wpływu sił ścinających na więzadło ACL. W przypadku, gdy grupa mięśni kulszowo goleniowych jest zbyt słaba by przeciwstawiać się tym siłom, więzadło ACL jest narażone na wysokie ryzyko uszkodzenia (Bencke i Zebis 2011).

\section{Dominacja kończyny}

Analiza roli i wpływu dominacji kończyny dolnej na ryzyko urazu więzadła ACL w grupie piłkarek i piłkarzy prowadzona była przez Brophy i współpracowników. W tym retrospektywnym badaniu prowadzonym na grupie 41 zawodników i 52 zawodniczek autorzy odnotowali fakt, iż ponad połowa urazów więzadła ACL dotyczyła kończyny dominującej (53 urazy na 99 ogólnie zarejestrowanych). Kończyna dominująca urazowi ulegała w przypadku 32,26\% kobiet oraz 74,07\% mężczyzn ( $<$ <.002) (Brophy i wsp. 2010). Zależność pomiędzy dominacją kończyny a urazem, w tym uszkodzeniem więzadła ACL pozostaje niejasna, i potrzeba więcej badań aby wypracować konsensus dotyczący grupy zawodniczek piłki nożnej. 
Level of athletic conditioning

Heidt et al. analysed the influence of the pre-season athletic conditioning on the incidence and type of injury in female football players. 300 female footballers aged 14-18 years were under observation for over a year. In a group which participated in a 7-week pre-season preparatory athletic conditioning, the percentage ratio of ACL injury was lower than in the other group which did not take part in such conditioning $(2.4 \%$ and $3.1 \%$, respectively). Based on these results we can conclude that the preparatory training may be important in reducing the number of injuries in young female athletes (Heidt et al. 2000).

\section{Playing field surface}

There are not many prospective studies examining the relation between the ACL injury and the surface on which female footballers play and practice. Soligard et al. studied a population of over 60,000 male and female players aged $13-19$ years, and did not discover any difference in the general risk of acute injury among athletes playing on third-generation synthetic turf and those playing on natural grass (Soligard et al. 2010). Similarly, Hagglund and Walden analysed the dependence of acute knee injury incidence, including 21 ACL injuries, in a group of 4,556 players who were watched throughout the entire season. They confirmed no difference in the incidence of these injuries when playing on artificial turf or natural surface (Hägglund and Waldén 2015). It seems that in this context it is the frequent change of playing surface, from various types of artificial turf to natural grass, that may significantly increase injury incidence in both male and female football players (Williams et al. 2011).

Aerobic endurance training It seems justified to include the level of aerobic endurance to injury risk factors, because
Poziom przygotowania motorycznego

Heidt $i$ wsp. przeanalizowali wpływ przedsezonowego przygotowania motorycznego na występowanie i rodzaj kontuzji w grupie piłkarek nożnych. 300 zawodniczek, w wieku 14-18 lat było włączonych do ponad rocznej obserwacji. W grupie, która uczestniczyła w 7-tygodniowym przedsezonowym treningu przygotowawczym odnotowano niższe wskaźniki procentowe uszkodzenia więzadła ACL $(2,4 \%)$ w porównaniu do grupy, która w takim treningu nie uczestniczyła $(3,1 \%)$. W oparciu o te wyniki można wnioskować, że tego rodzaju trening przygotowawczy może mieć istotne znaczenie w redukcji liczby urazów w grupie młodych zawodniczek (Heidt $i$ wsp. 2000).

Nawierzchnia boiska

Brak jest wielu prospektywnych badań analizujących zależność pomiędzy urazem więzadła ACL a nawierzchnią, na której piłkarki grają i trenują. Soligard $i$ wsp. w badaniach na populacji ponad 60.000 zawodniczek i zawodników w wieku 13-19 lat nie odnotowali różnic w ogólnym ryzyku urazów wśród osób grających na nawierzchni sztucznej III generacji w porównaniu do tych grających na naturalnej nawierzchni (Soligard i wsp. 2010). Podobnie Hagglund i Walden analizując zależności wystąpienia urazów stawu kolanowego, w tym 21 uraów więzadła ACL, w grupie 4556 zawodniczek obserwowanych przez cały sezon potwierdzają brak różnic w częstości występowania tych urazów gdy gra się na sztucznej lub naturalnej nawierzchni (Hägglund i Waldén 2015). Wydaje się, że w tym kontekście to czynnikiem, który w znaczny sposób predestynuje do kontuzji wśród zawodniczek i zawodników może być częsta zmiana nawierzchni na której się gra, z nawierzchni naturalnej na sztuczną, różnego rodzaju (Williams i wsp. 2011).

Przygotowanie tlenowe

Postrzeganie poziomu przygotowania tlenowego jako czynnika ryzyka kontuzji wydaje 
fatigue results in changes of muscle recruitment patterns. The changed patterns may in turn lead to changes in the distribution of forces affecting the joint, ligament, and muscle structures, and may therefore induce injury. Still, the dependency between aerobic endurance conditioning and injury risk is difficult to verify; it may be explained in part by different techniques used to assess aerobic endurance (Murphy et al. 2003).

Body mass index

The authors found no studies directly analysing the relation between the body mass index (BMI) value and ACL injury risk. Ostenborg and Roos have not included the $\mathrm{BMI}$ as a risk factor for all types of injuries in female football players (Ostenberg and Roos 2000). Nilstadt et al. , in turn, proved in their comprehensive analysis that higher BMI value has a statistical influence on the frequency of lower extremity injury (OR, 1.51; 95\% CI, 1.21-1.90; $\mathrm{p}=0,001$ ). The study was conducted on 173 Norwegian female football elite players. All the players underwent screening tests before the start of the season. During the season all injury incidents were recorded. 171 injuries were recorded among 107 players, the most common being muscle and joint injuries (Nilstad et al. 2014).

\section{Biomechanical factors}

The analysis of biomechanical factors related to injury risk and sex is most often conducted in laboratory conditions, using 3D measurement devices, tensometric platform, and devices used to record muscle biopotentials. Hart et al. studied a group of female and male football players, and the analysis of jumping biomechanics revealed that men had a statistically higher value of the knee adduction than women się rozsądne, ponieważ zmęczenie skutkuje zmianą wzorców rekrutacji mięśni. Z kolei, ten zmieniony wzorzec może doprowadzić do zmiany rozkładu sił działających na staw, więzadła i struktury mięśniowe i tym samym może prowokować powstanie urazu. Zależność pomiędzy przygotowaniem tlenowym a ryzykiem urazu jest jednak trudna do jednoznacznego zweryfikowania; może być wyjaśniona w części przez różne techniki stosowane do określania wydolności tlenowej (Murphy i wsp. 2003).

\section{Wskaźnik masy ciała}

Nie znaleziono prac bezpośrednio analizujących zależność pomiędzy wartością wskaźnika masy ciała (BMI) a ryzykiem uszkodzenia więzadła ACL. Ostenberg i Roos nie wskazali wartości wskaźnika BMI jako czynnika ryzyka wszystkich urazów w grupie piłkarek nożnych (Ostenberg i Roos 2000). Z kolei Nilstadt $i$ wsp. przeprowadzając analizę wieloczynnikową wykazali, że wyższa wartość wskaźnika BMI statystycznie wpływa na częstsze występowanie kontuzji kończyn dolnych (OR, 1,51 ; 95\% CI, 1,21-1,90; $\mathrm{p}=0$,001). Badania prowadzono na 173 zawodniczkach norweskich najwyższego poziomu rozgrywek. Przed przystąpieniem do rozgrywek wszystkie zawodniczki ukończyły testy przesiewowe, a w trakcie całego sezonu rejestrowano występujące urazy. Odnotowano 171 kontuzji wśród 107 zawodniczek, z czego najczęściej występowały uszkodzenia mięśni i więzadeł (Nilstad $i$ wsp. 2014).

\section{Uwarunkowania biomechaniczne}

Analiza uwarunkowań biomechanicznych ryzyka kontuzji stawu kolanowego w zależności od płci prowadzona jest najczęściej w warunkach laboratoryjnych, z wykorzystaniem 3-płaszczyznowych urządzań pomiarowych, platform tensometrycznych i urządzeń do rejestracji biopotencjałów mięśniowych. Hart $i$ wsp. w swoich badaniach prowadzonych na grupie zawodniczek i zawodników piłki nożnej odnotowali

92 Issues of Rehabilitation, Orthopaedics, Neurophysiology and Sport Promotion - IRONS 
(Hart et al. 2008). They observed higher values of internal rotation of the hip joint with concomitant reduced rotation of the lower extremity in women during the landing phase (Hart et al. 2008). The position - increased internal rotation of the hip joint with internally rotated tibia and knee moving to extension - is considered a common mechanism of ACL injury (Ireland 1999).

\section{Nonmodifiable factors of ACL injury risk}

Sex

It is well grounded in the literature that women are far more likely to suffer injuries, and ACL injuries in particular, than men. Among the factors increasing the risk of ACL injury in women much more than in men are: anatomic conditions, such as: the width of the intercondylar fossa of the femur, the tibia plateau anatomy, wider pelvis, larger knee valgus, greater value of the Q angle (Horton and Hall 1989; Moeller and Lamb 1997), greater joint flexibility (Söderman et al. 2001); hormonal factors (Dragoo et al. 2003), biomechanical factors (Sigward and Powers 2006), including the influence of the lower extremity dominance (Brophy et al. 2010), lower muscle strength (Bowerman et al. 2006), lower value of the Hcon/Qcon ratio (Söderman et al. 2001), lower value of hip and knee flexion, higher values of internal hip rotation, hip adduction, and external tibia rotation and adduction/abduction in the knee joint during high risk activity (Barber-Westin et al. 2009), different from male players neuromuscular control, manifested by increased activity of the quadriceps muscle and reduced activity of the hamstring muscle group (Huston and Wojtys 1996), and weaker than in men activity of the pelvic girdle muscles (Barber-Westin et al. 2009), poorer core stability wyższą statystycznie wartość momentu ustawienia szpotawego kolan u mężczyzn w porównaniu do kobiet podczas analizy ruchu skoku (Hart $i$ wsp. 2008). U kobiet obserwuje się wyższe wartości rotacji wewnętrznej w stawie biodrowym ze współtowarzysząca zmniejszoną rotacją kończyny dolnej u kobiet w fazy lądowania (Hart $i w s p$. 2008). Ta pozycja - zwiększona rotacja wewnętrzna stawu biodrowego ze zrotowaną zewnętrznie piszczelą i kolanem poruszającym się w kierunku wyprostu jest uznana za powszechny mechanizm urazu więzadła ACL (Ireli 1999).

\section{Niemodyfikowalne czynniki ryzyka uszko- dzenia ACL \\ Pteć}

W literaturze szeroko udowodnione jest, że kobiety zdecydowanie częściej ulegają kontuzjom, zwłaszcza uszkodzeniu więzadła ACL niż mężczyźni. Wśród czynników zwiększających ryzyko uszkodzenia więzadła ACL u zawodniczek w porównaniu do zawodników najczęściej wymienia się: uwarunkowania anatomiczne takie jak: szerokość dołu między kłykciowego, anatomia plateau piszczeli, szerszą miednicę, większą koślawość kolan, większą wartość kąta Q (Horton i Hall 1989; Moeller i Lamb 1997), większą elastyczność więzadłowa (Söderman $i$ wsp. 2001), czynniki hormonalne (Dragoo $i$ wsp. 2003), uwarunkowania biomechaniczne (Sigward i Powers 2006), w tym wpływ dominacji kończyny dolnej (Brophy $i$ wsp. 2010), niższy poziom siły mięśniowej (Bowerman $i$ wsp. 2006), mniejszą wartość wskaźnika Hcon/Qcon (Söderman $i$ wsp. 2001), mniejsze wartości zgięcia stawu biodrowego i kolanowego oraz większe wartości rotacji wewnętrznej biodra, przywodzenia w stawie biodrowym oraz zewnętrznej rotacji piszczeli i przywodzenia/ odwodzenia w stawie kolanowym w trakcie aktywności wysokiego ryzyka (Barber-Westin $i$ wsp. 2009), odmienną w stosunku do zawodników kontrolę nerwowo-mięśniową przejawiającą się zwiększoną aktywnością 
control (Barber-Westin and Noyes 2011), lower resilience to fatigue (Barber-Westin and Noyes 2011) and different muscle stiffness (Cammarata and Dhaher 2008) and movement patterns (Ford et al. 2006).

Previous injury

The influence of the previous injury on the risk of reinjury was analysed by several researchers (Faude et al. 2006; Nilstad et al. 2014; Hägglund and Waldén 2015). The risk of ACL reinjury was statistically higher among female football players who already suffered such an injury (Faude et al. 2006). It was also proved that a previous knee joint injury was associated to new injuries of the lower extremity and foot (OR, 3.57; 95\% CI, 1.27-9.99; $\mathrm{P}=0.02$ ) (Nilstad et al. 2014). Researchers confirmed as well that there is a relation between the injuries the players suffered and their familial dispositions to ACL injury. Young players whose familial dispositions to ACL injury were confirmed during the interview face greater risk of ACL injury and acute knee injuries (HR 1.96; 95\% CI:1.223.16) (Hägglund and Waldén 2015). The influence of the previous injury on the incidence of reinjury was also confirmed in a research conducted in a group of footballers. Football players with reconstructed ACL had a higher incidence of new knee joint injuries of all kinds as compared to footballers without a history of ACL reconstruction (Walden et al. 2006).

\section{Anatomic conditions}

Research confirms that there are morphological differences in the width of the intercondylar fossa of the femur between mięśnia czworogłowego i zmniejszoną aktywnością grupy kulszowo-goleniowej (Huston i Wojtys 1996) i słabszą w porównaniu do mężczyzn aktywnością mięśni obręczy biodrowej (Barber-Westin $i$ wsp. 2009), niższą kontrolę napięcia centralnego (Barber-Westin i Noyes 2011), mniejszą odporność na zmęczenie (Barber-Westin i Noyes 2011) oraz odmienną sztywność mięśniową (Cammarata i Dhaher 2008) i wzorce ruchowe (Ford $i$ wsp. 2006).

\section{Poprzednia kontuzja}

Wpływ poprzedniego urazu na ryzyko kolejnej kontuzji analizowany był przez kilku badaczy (Faude $i$ wsp. 2006; Nilstad $i$ wsp. 2014; Hägglund i Waldén 2015). Ryzyko ponownego uszkodzenia więzadła ACL było statystycznie wyższe wśród zawodniczek które wcześniej doznały już takiego urazu (Faude $i$ wsp. 2006). Wykazano także, że wcześniejsza kontuzja stawu kolanowego wiązała się z nowymi urazami kończyny dolnej i stopy (OR, 3,57; 95\% CI, 1,27-9,99; $\mathrm{P}=$ 0,02) (Nilstad $i$ wsp. 2014). Potwierdzono także zależność pomiędzy kontuzjami, którym uległy zawodniczki a ich rodzinnymi skłonnościami do uszkodzenia więzadła ACL. Młode zawodniczki z potwierdzonymi w wywiadzie rodzinnymi skłonnościami uszkodzenia więzadła ACL mają zwiększone ryzyko uszkodzenia tego więzadła i urazów stawu kolanowego (HR 1,96; 95\% CI:1,22-3,16) (Hägglund i Waldén 2015). Wpływ poprzedniej kontuzji na częstotliwość występowania kolejnej potwierdzono także w badaniach na grupie piłkarzy. Zawodnicy po rekonstrukcji więzadła ACL mieli wyższą częstość występowania nowych urazów stawu kolanowego dowolnego typu w porównaniu z zawodnikami bez historii rekonstrukcji więzadła ACL (Walden $i$ wsp. 2006).

Uwarunkowania anatomiczne

Badania potwierdzają istnienie morfologicznych różnic w szerokości dołu międzykłykciowego pomiędzy grupą kobiet

94 Issues of Rehabilitation, Orthopaedics, Neurophysiology and Sport Promotion - IRONS 
women who suffered an ACL injury and women whose ACL was not injured. The average width of the intercondylar fossa of the femur among women with ACL injury was $15.76 \mathrm{~mm}$, and it was statistically narrower as compared to healthy women (18.52 mm, p<0.001) (Park et al. 2012). It is difficult to unambiguously indicate the morphological values of the tibial plateau which would indicate the likelihood of injury, as various researchers obtained different and contradictory results. However, based on the conducted metaanalysis it can be confirmed that there are significant differences in the structure of the tibial plateau among persons who suffered a damage of ACL, and persons without such an injury (Wordeman et al. 2012). Moreover, persons with ACL injury had a significantly greater lateral inclination of the tibial plateau than persons without ACL issues. Average lateral tibial plateau slope in persons with healthy ACL was from $0.3^{\circ} \pm 3.6^{\circ}$ of anterior lateral tibial slope to $9^{\circ} \pm 4^{\circ}$ of posterior lateral tibial plateau slope; in persons with an ACL injury the slope was from $1.8^{\circ} \pm 3.2^{\circ}$ to $11.5^{\circ} \pm 3.54^{\circ}$, respectively. The medial tibial plateau slope was from $2.9^{\circ} \pm 2.8^{\circ}$ of anterior slope to $9.5^{\circ} \pm 3^{\circ}$ of posterior slope among persons without ACL damage, and from $1.8^{\circ} \pm 3.5^{\circ}$ to $12.1^{\circ} \pm 3.3^{\circ}$, respectively, for persons with ACL injury (Wordeman et al. 2012). Additionally, researchers noted the differences in the structure of articular surface of the proximal tibial epiphysis, which may contribute to ACL injuries. Posterior-inferior direction of articular surface was observed in women with ACL damage; in healthy women, the direction was posterior-superior (Beynnon et al. 2014). The increased value of the $Q$ angle is also considered as a risk factor for knee joint injuries. The $\mathrm{Q}$ angle is the angle formed by a line drawn from the ASIS to central patella and a second line drawn from central patella to tibial tubercle. The mean value of the $\mathrm{Q}$ angle for women is $15.8^{\circ} \pm 4.5^{\circ}$, and for men $11.2^{\circ} \pm 3.0^{\circ}$ (Horton and Hall z uszkodzeniem więzadła ACL oraz bez tego uszkodzenia. Średnia wartość szerokości dołu międzykłykciowego kości udowej wśród kobiet z uszkodzoniem więzadła ACL wynosiła $15,76 \mathrm{~mm}$ i była statystycznie mniejsza $\mathrm{w}$ porównaniu do $18,52 \mathrm{~mm}$ w grupie kobiet zdrowych $(\mathrm{p}<0,001)$ (Park $i$ wsp. 2012). Jednoznaczne wskazanie wartości morfologicznych plateau piszczeli predestynujących do urazów jest trudne ze względu na różnorodne sprzeczne wyniki uzyskiwane przez różnych badaczy. W oparciu o przeprowadzoną metaanalizę można jednak potwierdzić, iż istnieją znamienne różnice $\mathrm{w}$ budowie plateau piszczeli pomiędzy grupą osób, u których doszło do uszkodzenie więzadła ACL a grupą osób bez tego urazu (Wordeman $i$ wsp. 2012). Odnotowano znacząco większe nachylenia boczne plateau piszczeli (NBPP) w grupie osób z uszkodzeniem więzadła ACL w porównaniu do grupy osób bez urazu. Średnie wartości NBPP w grupie osób bez urazu wynosiły od $0,3^{\circ} \pm 3,6^{\circ}$ przedniego nachylenia do $9^{\circ} \pm 4^{\circ}$ tylnego nachylenia, podczas gdy $\mathrm{w}$ grupie $\mathrm{z}$ urazem wynosiły odpowiednio od $1,8^{\circ} \pm 3.2^{\circ}$ do $11,5^{\circ} \pm 3,54^{\circ}$. Nachylenia przyśrodkowe plateau piszczeli (NPPP) wynosiły od $2,9^{\circ} \pm 2,8^{\circ}$ przedniego nachylenia do $9,5^{\circ} \pm 3^{\circ}$ tylnego nachylenia w grupie osób bez urazu i odpowiednio od $1,8^{\circ} \pm 3,5^{\circ}$ do $12,1^{\circ} \pm 3,3^{\circ} \mathrm{w}$ grupie osób z uszkodzonym więzadłem ACL (Wordeman $i$ wsp. 2012). Dodatkowo, wskazuje się na różnice w budowie powierzchni stawowej nasady bliższej piszczeli, które mogą przyczyniać się do urazu więzadła ACL. Zaobserwowano tylno-dolny kierunek orientacji powierzchni stawowej w grupie kobiet z uszkodzonym więzadłem ACL, podczas gdy w grupie kontrolnej kierunek ten był tylno-górny (Beynnon $i$ wsp. 2014). Zwiększona wartość kąta Q uznawana jest także jako czynnik ryzyka uszkodzenia stawu kolanowego. Kąt Q opisywany jest jako kąt zawarty pomiędzy linia długą uda, a linią przebiegającą wzdłuż piszczeli. Średnia wartość kąta Q dla kobiet wynosi $15,8^{\circ} \pm 4,5^{\circ}$, a dla mężczyzn 
1989). Higher values of the $Q$ angle in women are caused by wider pelvis, which increases the femoral slope and leads to valgus knee. It is assumed that the greater the $\mathrm{Q}$ angle, the greater the risk of patellar instability and the greater the risk of anterior knee pain, and the greater the likelihood of ACL injury (Moeller and Lamb 1997). It has been long suggested that there is a relationship between the systemic elasticity and knee joint injuries, including ACL injuries in female football players (Ostenberg and Roos 2000). Myer et al. found that compared to the control group, female footballers with knee joint hyperextention were five times more likely to suffer ACL injuries (Myer et al. 2008). Using anthropometric measurements researchers proved that women (both football players and women who do not play football) have greater joint elasticity than men (Huston and Wojtys 1996; Hewett 2005; Barber-Westin and Noyes 2011). Previous studies showed that greater knee joint elasticity (Shultz et al. 2007; Barber-Westin and Noyes 2011) and increased systemic elasticity (Cammarata and Dhaher 2008; Quatman et al. 2008) are more common among adolescent girls than boys. Excessive knee joint elasticity may potentially be related to ACL injury risk (Ford et al. 2006; Myer et al. 2008).

Hormonal factors

Increasingly often studies focus on the relationship between the level of sex hormones in the different phases of the menstrual cycle and risk of injury in female football players. Research shows that fluctuations in the concentration of sex hormones influence the knee joint tension. $11,2^{\circ} \pm 3,0^{\circ}$ stopnia (Horton i Hall 1989). Wyższe wartości kąta Q u kobiet wynikają z faktu, że kobiety mają szerszą niż mężczyźni miednicę, co zwiększa nachylenie kości udowych i w konsekwencji prowadzi do koślawego ustawienia kolan. Przypuszcza się, że im większy kąt Q, tym większe ryzyko niestabilności rzepki i większe ryzyko bólu przedziału przedniego stawu kolanowego, a także zwiększone prawdopodobieństwo uszkodzenia ACL (Moeller i Lamb 1997). Od dawna sugeruje się, iż istnieje zależność pomiędzy elastycznością ogólnoukładową a kontuzjami stawu kolanowego, włączając w to uraz ACL w grupie piłkarek nożnych (Ostenberg i Roos 2000). Myer $i$ wsp. stwierdzili, że zawodniczki, które miały przeprost stawu kolanowego były pięć razy bardziej narażone na uszkodzenie więzadła ACL w porównaniu do grupy kontrolnej (Myer i wsp. 2008). Wykorzystując pomiary antropometryczne dowiedziono, że kobiety (zarówno zawodniczki jak i osoby nietrenujące) charakteryzują się wyższą elastycznością stawową niż mężczyźni (Huston i Wojtys 1996; Hewett 2005; Barber-Westin i Noyes 2011). Wcześniejsze badania wykazały, że większa elastyczność więzadłowa stawu kolanowego (Shultz i wsp. 2007; Barber-Westin i Noyes 2011) i zwiększona elastyczność ogólnoukładowa (Cammarata i Dhaher 2008; Quatman $i$ wsp. 2008) są bardziej powszechne w grupie dorastających dziewcząt niż u ich kolegów. Nadmierna elastyczność stawu kolanowego jest potencjalnym czynnikiem, który może być powiązany z ryzykiem uszkodzenia ACL (Ford $i$ wsp. 2006; Myer i wsp. 2008).

Uwarunkowania hormonalne

Coraz szerzej doszukuje się zależności pomiędzy poziomem hormonów płciowych w poszczególnych fazach cyklu menstruacyjnego a ryzykiem urazów w grupie zawodniczek. Badania wskazują, iż wahania koncentracji hormonów płciowych wpływają na zmianę napięcia więzadeł stawu 
Nevertheless, the degree of dependency and the relative influence of each hormone vary among women (Shultz et al. 2004). The variations of sex hormones in the menstrual cycle seem to affect the kinaesthesia of the knee joint and the neuromuscular coordination. In a study of 25 healthy women abnormal knee joint kinaesthesia was discovered in the pre-ovulation phase, and compared with other phases of the cycle the results of the hop test greatly improved in the ovulation phase (Fridén et al. 2006). Research has proved that there is a significantly higher incidence of non-contact ACL injuries among female football players during the pre-ovulation phase of the menstrual cycle (Wojtys et al. 2002).

\section{Age of players}

No studies clearly indicate any dependency between age and ACL injury among female football players. Still, there are papers corroborating that the general number of injuries in football may be dependent on the age of players. Hagglund et al. in their study of the Swedish female football league spanning one season (228 players from 12 clubs) reported the following percentage values of injuries among different age groups: $<20$ years old (26\%), 21-25 years old (37\%), $26-30$ years old (32\%), > 30 years old (3\%) (Hägglund et al. 2009). The most common injuries occurred among players aged 25 years and more. The same was observed in the study by Ostenberg et al. (Ostenberg and Roos 2000). Norwegian and Swedish studies confirm that there is a statistical difference between male and female footballers in the age at which ACL injuries occur. Female players are statistically younger (19 years old) than male players (23 (Roos et al. 1995) or 27 (Bjordal et al. 1997) years old) when they suffer ACL injuries. Another study showed that women are on average four years younger than men when they suffer an ACL injury (they are 21 and 25 years old, respectively) (Waldén et al. 2010). kolanowego. Niemniej siła tej zależności oraz relatywny udział każdego z hormonów są zróżnicowane pomiędzy kobietami (Shultz $i$ wsp. 2004). Zmienność poziomu hormonów płciowych w cyklu menstruacyjnego wydaje się mieć wpływ na kinestezję stawu kolanowego i koordynację nerwowo-mięśniową. W badaniu z udziałem 25 zdrowych kobiet zaburzenia w kinestezji stawu kolanowego zostały wykryte $\mathrm{w}$ fazie przedowulacyjnej a jakość wykonania testów przeskoku znacznie poprawiła się $\mathrm{w}$ fazie owulacji w porównaniu $\mathrm{z}$ innymi fazami cyklu (Fridén $i$ wsp. 2006). Wykazano istotnie większą częstość występowania bezkontaktowych urazów ACL wśród zawodniczek w trakcie fazy przedowulacyjnej cyklu miesiączkowego (Wojtys $i$ wsp. 2002).

Wiek zawodniczek

Brak badań jednoznacznie wskazujących na zależność pomiędzy wiekiem a urazem więzadła ACL w grupie piłkarek nożnych. Niemniej, są prace potwierdzające, iż ogólna liczba kontuzji piłkarskich uzależniona może być od wieku zawodniczek. Hagglund $i$ wsp. w trakcie obserwacji jednego sezonu ligi szwedzkiej (228 zawodniczek z 12 klubów) odnotowali następujące wartości procentowe kontuzji wśród poszczególnych grup wiekowych: $<20$ lat (26\%), $21-25$ lat (37\%), 26 - 30 lat (32\%), > 30 lat (3\%) (Hägglund $i$ wsp. 2009). Najczęściej urazy występowały w grupie zawodniczek powyżej 25 roku życia, co obserwowane było także w badaniu Ostenberg $i$ wsp. (Ostenberg i Roos 2000). Norweskie i szwedzkie badania potwierdzają, że istnieje statystyczna różnica w wieku, w którym dochodzi do uszkodzenia więzadła ACL w grupie piłkarek w porównaniu do piłkarzy. Zawodniczki są statystycznie młodsze (mają 19 lat) w porównaniu do zawodników (mają 23 (Roos $i$ wsp. 1995) lub 27 (Bjordal $i$ wsp. 1997) lat), gdy uszkadzają więzadło ACL. W innym badaniu odnotowano, że kobiety są średnio o 4 lata młodsze, gdy dochodzi u nich do urazu więzadła ACL w porównaniu 
z mężczyznami (odpowiednio: 21 i 25 lat)

(Waldén $i$ wsp. 2010).

Skill level

Prospective studies conducted on a group of over 1600 Norwegian female players aged 13-17 years revealed that players with higher technical football skills suffered injuries far more often (Soligard et al. 2010). The number of injuries in the group was from 4.4 to 4.9 injury per 1000 hours, compared to $2.8-4.0$ injury per 1000 hours in female footballers with lower technical and motor skills. Players who perform better in passing, shots, head shots, who made faster decisions while keeping the ball, and players who are physically stronger face greater risk of injury, especially acute and contact injury) than their teammates with lower skills (injury ratio $1.50-3.19, \mathrm{p}<0.05$ ) (Soligard et al. 2010).

\section{Discussion and conclusions}

Summing up, in order to optimally prevent injuries, including ACL injuries, in female football it is crucial to know how to identify players with higher risk of injury. For that purpose we should conduct regular, comprehensive functional and biomechanical tests to detect characteristic disorders predisposing female football players to most common sports injuries. Physiotherapists, doctors and coaches participating in screening, training and treatment process of players should be aware of warning signs indicating the possibility of injury. It should be emphasized, however, that despite the risk factors of ACL injury described above, the actual prediction of ACL injuries is difficult. Retrospective and case-control studies are flawed, as they do not allow for a multifactorial analysis, which should be conducted among female football players in a comprehensive risk assessment of lower limb injuries. On the other hand, in prospective
Poziom umiejętności

W prospektywnych badaniach prowadzonych na grupie ponad 1600 zawodniczek norweskich w wieku 13-17 lat zaobserwowano, że zdecydowanie częściej urazom ulegały piłkarki reprezentujące wyższy poziom umiejętności technicznych (Soligard i wsp. 2010). Liczba urazów w tej grupie wynosiła od 4,4 do 4,9 uraza na 1000 godzin, w porównaniu do wartości od 2,8 do 4,0 na 1000 godzin w grupie piłkarek o niższych umiejętnościach techniczno-motorycznych. Zawodniczki lepiej radzace sobie w podaniach, strzałach, strzałach głową, szybciej podejmujące decyzje $\mathrm{w}$ trakcie utrzymywania piłki a także zawodniczki fizycznie silniejsze cechuje znacznie większe ryzyko kontuzji, zwłaszcza urazów kontaktowych niż mniej wyszkolone koleżanki z drużyny (wskaźnik kontuzji 1,50 vs. 3,19, p<0,05) (Soligard $i$ wsp. 2010).

\section{Omówienie i wnioski}

Podsumowując można stwierdzić, że aby optymalnie przeciwdziałać wystąpieniu kontuzji w piłce nożnej kobiet, konieczna jest umiejętność i możliwość identyfikacji zawodniczek o zwiększonym ryzyku urazu sportowego, np.: uszkodzenia więzadła ACL. W tym celu regularnie należy stosować kompleksowe testy funkcjonalne i biomechaniczne pozwalające wychwycić charakterystyczne zaburzenia predestynujące piłkarki nożne do urazów sportowych najczęściej występujących w tej grupie. Fizjoterapeuci, lekarze i trenerzy uczestniczących w badaniach przesiewowych, treningu i w procesie leczenia zawodniczki powinni być świadomi znaków ostrzegawczych wskazujących na możliwość wystąpienia urazu. Trzeba jednak podkreślić, iż pomimo opisanych powyżej czynników ryzyka uszkodzenia więzadła ACL w grupie piłkarek nożnych, faktyczna predykcja tych kontuzji jest trudna do jednoznacznego określenia. 
studies, where risk assessment is based on e.g. joint laxity or muscle strength, it is very difficult to obtain the values of these parameters immediately after the injury due to pain suffered by the athletes. Thus, the results of tests may be unreliable (Murphy et al. 2003). In addition, a frequent limitation of the published works lies also in the insufficient number of subjects in each group (e.g.: women with ACL injury, men with ACL injury, women without ACL injury, men without ACL injury) which affects the direct application of the studies in predicting sports injuries. If the number of subjects is too low compared to the number of analysed factors (e.g. during a multifactorial analysis), there is a high risk of a statistical error type II, which leads to flawed results (Barber-Westin et al. 2009).
Badania retrospektywne i kliniczno-kontrolne są obarczone błędem ponieważ nie w pełni pozwalają na wieloczynnikową analizę, która powinna być przeprowadzona w grupie zawodniczek w kontekście kompleksowej oceny ryzyka urazów kończyn dolnych. Z kolei w badaniach prospektywnych, gdzie jednym ze sposobów oceny ryzyka jest np.: wiotkość stawowa albo wartość siły mięśniowej, jest bardzo trudno uzyskać wartości tych parametrów bezpośrednio po urazie wskutek bólu towarzyszącego temu urazowi. Tym samym uzyskane wyniki mogą być niewiarygodne (Murphy i wsp. 2003). Dodatkowo, częstym ograniczeniem publikowanych prac i ich bezpośredniego zastosowania w przewidywaniu kontuzji sportowych jest także niewystarczająca liczebność osób w poszczególnych grupach (np.: kobiet z uszkodzeniem ACL, mężczyzn z uszkodzeniem ACL, kobiet bez uszkodzenia ACL, mężczyzn bez uszkodzenia ACL). Przy zbyt niskich liczebnościach badanych osób w porównaniu do liczby analizowanych czynników (np. w trakcie przeprowadzenia analizy wieloczynnikowej) istnieje duże ryzyko popełnienia błędu statystycznego II rodzaju, i tym samym uzyskania wyników obarczonych błędem (Barber-Westin $i$ wsp. 2009). 


\section{REFERENCES}

Barber-Westin, S. D., Noyes, F. R., Smith, S. T. and Campbell, T. M. (2009) 'Reducing the risk of noncontact anterior cruciate ligament injuries in the female athlete.' Phys Sportsmed 37, pp. 49-61.

Barber-Westin, S., Noyes, F. (2011) 'Objective Criteria for Return to Athletics After Anterior Cruciate Ligament Reconstruction i Subsequent Reinjury Rates: A Systematic Review.' Phys Sportsmed 39, pp. 100-110. Bencke, J., Zebis, M. K. (2011) 'The influence of gender on neuromuscular pre-activity during side-cutting. J Electromyogr Kinesiol 21, pp. 371-375.

Beynnon, B. D., Vacek, P. M., Sturnick, D. R., Holterman, L. A., Gardner-Morse, M., Tourville, T. W., Smith, H. C., Slauterbeck, J. R., Johnson, R. J. and Shultz, S. J. (2014) 'Geometric profile of the tibial plateau cartilage surface is associated with the risk of non-contact anterior cruciate ligament injury.' J Orthop Res 32, pp. 61-68. Bjordal, J. M., Arnły, F., Hannestad, B. and Stri, T. (1997) 'Epidemiology of anterior cruciate ligament injuries in soccer.' Am J Sports Med 25, pp. 341-345.

Bowerman, S. J., Smith, D. R., Carlson, M. and King, G. A. (2006) 'A comparison of factors influencing ACL injury in male $i$ female athletes i non-athletes'. Phys Ther Sport 7, pp. 144-152.

Brophy, R., Silvers, H. J., Gonzales, T. and Mielbaum, B. R. (2010) 'Gender influences: the role of leg dominance in ACL injury among soccer players.' Br J Sports Med 44, pp. 694-697.

Cammarata, M. L., Dhaher, Y. Y. (2008) 'The differential effects of gender, anthropometry, i prior hormonal state on frontal plane knee joint stiffness.' Clin Biomech 23, pp. 937-945.

Dragoo, J. L., Lee, R. S., Benhaim, P., Finerman, G. A. M. and Hame, S. L. (2003) 'Relaxin receptors in the human female anterior cruciate ligament.' Am J Sports Med 31, pp. 577-584.
PIŚMIENNICTWO

Barber-Westin, S. D., Noyes, F. R., Smith, S. T. and Campbell, T. M. (2009) 'Reducing the risk of noncontact anterior cruciate ligament injuries in the female athlete.' Phys Sportsmed 37, str. 49-61.

Barber-Westin, S., Noyes, F. (2011) 'Objective Criteria for Return to Athletics After Anterior Cruciate Ligament Reconstruction i Subsequent Reinjury Rates: A Systematic Review.' Phys Sportsmed 39, str. 100-110. Bencke, J., Zebis, M. K. (2011) 'The influence of gender on neuromuscular pre-activity during side-cutting. J Electromyogr Kinesiol 21, str. 371-375.

Beynnon, B. D., Vacek, P. M., Sturnick, D. R., Holterman, L. A., Gardner-Morse, M., Tourville, T. W., Smith, H. C., Slauterbeck, J. R., Johnson, R. J. and Shultz, S. J. (2014) 'Geometric profile of the tibial plateau cartilage surface is associated with the risk of non-contact anterior cruciate ligament injury.' J Orthop Res 32, str. 61-68. Bjordal, J. M., Arnły, F., Hannestad, B. and Stri, T. (1997) 'Epidemiology of anterior cruciate ligament injuries in soccer.' Am J Sports Med 25, str. 341-345.

Bowerman, S. J., Smith, D. R., Carlson, M. and King, G. A. (2006) 'A comparison of factors influencing ACL injury in male $i$ female athletes $i$ non-athletes'. Phys Ther Sport 7, str. 144-152.

Brophy, R., Silvers, H. J., Gonzales, T. and Mielbaum, B. R. (2010) 'Gender influences: the role of leg dominance in ACL injury among soccer players.' Br J Sports Med 44, str. 694-697.

Cammarata, M. L., Dhaher, Y. Y. (2008)

'The differential effects of gender, anthropometry, i prior hormonal state on frontal plane knee joint stiffness.' Clin Biomech 23, str. 937-945.

Dragoo, J. L., Lee, R. S., Benhaim, P. , Finerman, G. A. M. and Hame, S. L. (2003) 'Relaxin receptors in the human female anterior cruciate ligament.' Am J Sports Med 31, str. 577-584. 
Faude, O., Junge, A., Kindermann, W. and Dvorak, J. (2006) 'Risk factors for injuries in elite female soccer players.' Br J Sports Med 40, pp. 785-790.

Ford, K. R., Myer, G. D., Smith, R. L., Vianello, R. M., Seiwert, S. L. and Hewett, T. E. (2006) 'A comparison of dynamic coronal plane excursion between matched male ifemale athletes when performing single leg liings.' Clin Biomech 21, pp. 33-40.

Fridén, C., Hirschberg, A. L., Saartok, T. and Renström, P. (2006) 'Knee joint kinaesthesia i neuromuscular coordination during three phases of the menstrual cycle in moderately active women.' Knee Surg Sports Traumatol Arthrosc 14, pp. 383-389.

Griffin, L. Y., Agel, J., Albohm, M. J., Arendt, E. A., Dick, R. W., Garrett, W. E., Garrick, J. G., Hewett, T. E., Huston, L. (2000) 'Noncontact anterior cruciate ligament injuries: risk factors i prevention strategies.' J Am Acad Orthop Surg 8, pp. 141-150.

Hägglund, M., Waldén, M. (2015) 'Risk factors for acute knee injury in female youth football.' Knee Surg Sports Traumatol Arthrosc. 24(3), pp. 737-46

Hägglund, M., Waldén, M., Ekstri, J. (2009) 'Injuries among male i female elite football players.' Sci J Med Sci Sports 19, pp. 819-827.

Hart, J., Garrison J., Pamieri-Smith, R., Kerrigan, D., Ingersoll C. (2008) 'Lower extremity joint moments of collegiate soccer players differ between genders during a forward jump.' J Sport Rehabil, 17(2), pp. 137-47

Heidt, R. S., Sweeterman, L. M., Carlonas, R. L., Traub, J. A. and Tekulve, F. X. (2000) 'Avoidance of soccer injuries with preseason conditioning.' Am J Sports Med 28, pp. 659-662.

Hewett, T. E. (2005) 'Biomechanical Measures of Neuromuscular Control $i$ Valgus Loading of the Knee Predict Anterior Cruciate Ligament Injury Risk in Female Athletes: A Prospective Study.' Am J Sports Med 33, pp. 492-501.
Faude, O., Junge, A., Kindermann, W. and Dvorak, J. (2006) 'Risk factors for injuries in elite female soccer players.' Br J Sports Med 40, str. 785-790.

Ford, K. R., Myer, G. D., Smith, R. L., Vianello, R. M., Seiwert, S. L. and Hewett, T. E. (2006) 'A comparison of dynamic coronal plane excursion between matched male ifemale athletes when performing single leg liings.' Clin Biomech 21, str. 33-40.

Fridén, C., Hirschberg, A. L., Saartok, T. and Renström, P. (2006) 'Knee joint kinaesthesia i neuromuscular coordination during three phases of the menstrual cycle in moderately active women.' Knee Surg Sports Traumatol Arthrosc 14, str. 383-389.

Griffin, L. Y., Agel, J., Albohm, M. J., Arendt, E. A., Dick, R. W., Garrett, W. E., Garrick, J. G., Hewett, T. E., Huston, L. (2000) 'Noncontact anterior cruciate ligament injuries: risk factors i prevention strategies.' J Am Acad Orthop Surg 8, str. 141-150. Hägglund, M., Waldén, M. (2015) 'Risk factors for acute knee injury in female youth football.' Knee Surg Sports Traumatol Arthrosc. 24(3), str. 737-46

Hägglund, M., Waldén, M., Ekstri, J. (2009) 'Injuries among male i female elite football players.' Sci J Med Sci Sports 19, str. 819-827.

Hart, J., Garrison J., Pamieri-Smith, R., Kerrigan, D., Ingersoll C. (2008) 'Lower extremity joint moments of collegiate soccer players differ between genders during a forward jump.' J Sport Rehabil, 17(2), str. $137-47$

Heidt, R. S., Sweeterman, L. M., Carlonas, R. L., Traub, J. A. and Tekulve, F. X. (2000) 'Avoidance of soccer injuries with preseason conditioning.' Am J Sports Med 28, str. 659-662.

Hewett, T. E. (2005) 'Biomechanical Measures of Neuromuscular Control $i$ Valgus Loading of the Knee Predict Anterior Cruciate Ligament Injury Risk in Female Athletes: A Prospective Study.' Am J Sports Med 33, str. 492-501.

101 Issues of Rehabilitation, Orthopaedics, Neurophysiology and Sport Promotion - IRONS 
Horton, M. G., Hall, T. L. (1989) 'Quadriceps femoris muscle angle: normal values $i$ relationships with gender i selected skeletal measures'. Phys Ther 69, pp. 897-901.

Huston, L. J., Wojtys, E. M. (1996) 'Neuromuscular performance characteristics in elite female athletes.' Am J Sports Med 24, pp. 427-436.

Ireli, M. L. (1999) 'Anterior cruciate ligament injury in female athletes: epidemiology.' J Athl Train 34, pp. 150-154.

Junge, A., Dvorak, J. (2007) 'Injuries in female football players in top-level international tournaments.' Br J Sports Med 41, pp. i3-i7. Lohmier, L. S., Stenberg, A., Englund, M. and Roos, H. (2004) 'High prevalence of knee osteoarthritis, pain, i functional limitations in female soccer players twelve years after anterior cruciate ligament injury.' Arthritis Rheum 50, pp. 3145-3152.

Moeller, J. L., Lamb, M. M. (1997) 'Anterior cruciate ligament injuries in female athletes: why are women more susceptible?' Phys Sportsmed 25, pp. 31-48.

Murphy, D. F., Connolly, D. A. J. and Beynnon, B. D. (2003) 'Risk factors for lower extremity injury: a review of the literature.' Br J Sports Med 37, pp. 13-29.

Myer, G. D., Ford, K. R., Paterno, M. V., Nick, T. G. and Hewett, T. E. (2008) 'The effects of generalized joint laxity on risk of anterior cruciate ligament injury in young female athletes.' Am J Sports Med 36, pp. 1073-1080.

Nilstad, A., Iersen, T. E., Bahr, R., Holme, I. and Steffen, K. (2014) 'Risk factors for lower extremity injuries in elite female soccer players.' Am J Sports Med 42, pp. 940-948. Ostenberg, A., Roos, H. (2000) 'Injury risk factors in female European football. A prospective study of 123 players during one season.' Sci J Med Sci Sports 10, pp. 279-285.

Park, J. S., Nam, D. C., Kim, D. H., Kim, H. K. and Hwang, S. C. (2012) 'Measurement of Knee Morphometrics Using MRI: A Comparative Study between ACL-Injured i Non-Injured Knees.' Knee Surg Relat Res 24, pp. 180-188.
Horton, M. G., Hall, T. L. (1989) 'Quadriceps femoris muscle angle: normal values $i$ relationships with gender $i$ selected skeletal measures'. Phys Ther 69, str. 897-901.

Huston, L. J., Wojtys, E. M. (1996) 'Neuromuscular performance characteristics in elite female athletes.' Am J Sports Med 24, str. 427-436.

Ireli, M. L. (1999) 'Anterior cruciate ligament injury in female athletes: epidemiology.' J Athl Train 34, str. 150-154.

Junge, A., Dvorak, J. (2007) 'Injuries in female football players in top-level international tournaments.' Br J Sports Med 41, str. i3-i7. Lohmier, L. S., Stenberg, A., Englund, M. and Roos, H. (2004) 'High prevalence of knee osteoarthritis, pain, i functional limitations in female soccer players twelve years after anterior cruciate ligament injury.' Arthritis Rheum 50, str. 3145-3152.

Moeller, J. L., Lamb, M. M. (1997) 'Anterior cruciate ligament injuries in female athletes: why are women more susceptible?' Phys Sportsmed 25, str. 31-48.

Murphy, D. F., Connolly, D. A. J. and Beynnon, B. D. (2003) 'Risk factors for lower extremity injury: a review of the literature.' Br J Sports Med 37, str. 13-29.

Myer, G. D., Ford, K. R., Paterno, M. V., Nick, T. G. and Hewett, T. E. (2008) 'The effects of generalized joint laxity on risk of anterior cruciate ligament injury in young female athletes.' Am J Sports Med 36, str. 1073-1080.

Nilstad, A., Iersen, T. E., Bahr, R., Holme, I. and Steffen, K. (2014) 'Risk factors for lower extremity injuries in elite female soccer players.' Am J Sports Med 42, str. 940-948. Ostenberg, A., Roos, H. (2000) 'Injury risk factors in female European football. A prospective study of 123 players during one season.' Sci J Med Sci Sports 10, str. 279-285.

Park, J. S., Nam, D. C., Kim, D. H., Kim, H. K. and Hwang, S. C. (2012) 'Measurement of Knee Morphometrics Using MRI: A Comparative Study between ACL-Injured i Non-Injured Knees.' Knee Surg Relat Res 24, str. 180-188. 
Quatman, C. E., Ford, K. R., Myer, G. D., Paterno, M. V. and Hewett, T. E. (2008) 'The effects of gender $i$ pubertal status on generalized joint laxity in young athletes.' J Sci Med Sport 11, pp. 257-263.

Roos, H., Ornell, M., Gärdsell, P., Lohmier, L. S. and Lindstri, A. (1995) 'Soccer after anterior cruciate ligament injury--an incompatible combination? A national survey of incidence $i$ risk factors $i$ a 7-year follow-up of 310 players.' Acta Orthop Sci 66, pp. 107-112.

Shultz, S. J., Kirk, S. E., Johnson, M. L., Sier, T. C. and Perrin, D. H. (2004) 'Relationship between sex hormones $i$ anterior knee laxity across the menstrual cycle'. Med Sci Sports Exerc 36, pp. 1165-1174.

Shultz, S. J., Shimokochi, Y., Nguyen, A.-D., Schmitz, R. J., Beynnon, B. D. and Perrin, D. H. (2007) 'Measurement of varus-valgus i internal-external rotational knee laxities in vivo-Part II: relationship with anterior-posterior i general joint laxity in males i females.' J Orthop Res 25, pp. 989-996. Sigward, S. M., Powers, C. M. (2006) 'The influence of gender on knee kinematics, kinetics $i$ muscle activation patterns during sidestep cutting.' Clin Biomech 21, pp. 41-48. Soligard, T., Bahr, R. and Iersen, T. E. (2010a) 'Injury risk on artificial turfi grass in youth tournament football.' Sci J Med Sci Sports 22, pp. 356-361.

Soligard, T., Grindem, H., Bahr, R. i Iersen, T. E. (2010b). 'Are skilled players at greater risk of injury in female youth football?' Br J Sports Med 44, pp. 1118-1123.

Söderman, K., Pietilä, T., Alfredson, H. and Werner, S. (2002) 'Anterior cruciate ligament injuries in young females playing soccer at senior levels.' Sci J Med Sci Sports 12, pp. 65-68.

Söderman, K., Alfredson, H., Pietilä, T. and Werner, S. (2001) 'Risk factors for leg injuries in female soccer players: a prospective investigation during one out-door season.' Knee Surg Sports Traumatol Arthrosc 9, pp. 313-321.
Quatman, C. E., Ford, K. R., Myer, G. D., Paterno, M. V. and Hewett, T. E. (2008) 'The effects of gender $i$ pubertal status on generalized joint laxity in young athletes.' J Sci Med Sport 11, str. 257-263.

Roos, H., Ornell, M., Gärdsell, S. , Lohmier, L. S. and Lindstri, A. (1995) 'Soccer after anterior cruciate ligament injury--an incompatible combination? A national survey of incidence $i$ risk factors i a 7-year follow-up of 310 players.' Acta Orthop Sci 66, str. 107-112.

Shultz, S. J., Kirk, S. E., Johnson, M. L., Sier, T. C. and Perrin, D. H. (2004) 'Relationship between sex hormones $i$ anterior knee laxity across the menstrual cycle'. Med Sci Sports Exerc 36, str. 1165-1174.

Shultz, S. J., Shimokochi, Y., Nguyen, A.-D., Schmitz, R. J., Beynnon, B. D. and Perrin, D. H. (2007) 'Measurement of varus-valgus i internal-external rotational knee laxities in vivo-Part II: relationship with anterior-posterior i general joint laxity in males i females.' J Orthop Res 25, str. 989-996. Sigward, S. M., Powers, C. M. (2006) 'The influence of gender on knee kinematics, kinetics i muscle activation patterns during sidestep cutting.' Clin Biomech 21, str. 41-48. Soligard, T., Bahr, R. and Iersen, T. E. (2010a) 'Injury risk on artificial turf $i$ grass in youth tournament football.' Sci J Med Sci Sports 22, str. 356-361.

Soligard, T., Grindem, H., Bahr, R. i Iersen, T. E. (2010b). 'Are skilled players at greater risk of injury in female youth football?' Br J Sports Med 44, str. 1118-1123.

Söderman, K., Pietilä, T., Alfredson, H. and Werner, S. (2002) 'Anterior cruciate ligament injuries in young females playing soccer at senior levels.' Sci J Med Sci Sports 12, str. 65-68.

Söderman, K., Alfredson, H., Pietilä, T. and Werner, S. (2001) 'Risk factors for leg injuries in female soccer players: a prospective investigation during one out-door season.' Knee Surg Sports Traumatol Arthrosc 9, str. 313-321.

103 Issues of Rehabilitation, Orthopaedics, Neurophysiology and Sport Promotion - IRONS 
Walden, M., Hägglund, M. and Ekstri, J. (2006) 'High risk of new knee injury in elite footballers with previous anterior cruciate ligament injury.' Br J Sports Med 40, pp. 158-62.

Waldén, M., Hägglund, M., Magnusson, H. and Ekstri, J. (2010a) 'Anterior cruciate ligament injury in elite football: a prospective three-cohort study.' Knee Surg Sports Traumatol Arthrosc 19, pp. 11-19.

Waldén, M., Hägglund, M., Werner, J. and Ekstri, J. (2010b) 'The epidemiology of anterior cruciate ligament injury in football (soccer): a review of the literature from a gender-related perspective.' Knee Surg Sports Traumatol Arthrosc 19, pp. 3-10. Williams, S., Hume, P. A., Kara, S. (2011) 'A review of football injuries on third i fourth generation artificial turfs compared with natural turf.' Sports Med 41, pp. 903-923. Wojtys, E. M., Huston, L. J., Boynton, M. D., Spindler, K. P. and Lindenfeld, T. N. (2002) 'The effect of the menstrual cycle on anterior cruciate ligament injuries in women as determined by hormone levels.' Am J Sports Med 30, pp. 182-188.

Wordeman, S. C., Quatman, C. E., Kaeding, C. C. and Hewett, T. E. (2012) 'In vivo evidence for tibial plateau slope as a risk factor for anterior cruciate ligament injury: a systematic review i meta-analysis.' Am J Sports Med. 40, pp. 1673-1681.

Authors reported no source of funding. Authors declared no conflict of interest.

Author responsible for correspondence: Monika Grygorowicz

Rehasport Clinic

ul. Górecka 30

60-201 Poznan, Poland

monika.grygorowicz@rehasport.pl
Walden, M., Hägglund, M. and Ekstri, J. (2006) 'High risk of new knee injury in elite footballers with previous anterior cruciate ligament injury.' Br J Sports Med 40, str. 158-62.

Waldén, M., Hägglund, M., Magnusson, H. and Ekstri, J. (2010a) 'Anterior cruciate ligament injury in elite football: a prospective three-cohort study.' Knee Surg Sports Traumatol Arthrosc 19, str. 11-19.

Waldén, M., Hägglund, M., Werner, J. and Ekstri, J. (2010b) 'The epidemiology of anterior cruciate ligament injury in football (soccer): a review of the literature from a gender-related perspective.' Knee Surg Sports Traumatol Arthrosc 19, str. 3-10. Williams, S., Hume, P. A., Kara, S. (2011) 'A review of football injuries on third i fourth generation artificial turfs compared with natural turf.' Sports Med 41, str. 903-923. Wojtys, E. M., Huston, L. J., Boynton, M. D., Spindler, K. P. and Lindenfeld, T. N. (2002) 'The effect of the menstrual cycle on anterior cruciate ligament injuries in women as determined by hormone levels.' Am J Sports Med 30, str. 182-188.

Wordeman, S. C., Quatman, C. E., Kaeding, C. C. and Hewett, T. E. (2012) 'In vivo evidence for tibial plateau slope as a risk factor for anterior cruciate ligament injury: a systematic review i meta-analysis.' Am J Sports Med. 40, str. 1673-1681.

Autorzy nie zgłaszali źródła finansowania. Autorzy nie deklarowali konfliktu interesów.

Autor odpowiedzialny za korespondencję: Monika Grygorowicz

Rehasport Clinic

ul. Górecka 30

60-201 Poznań, Polska

monika.grygorowicz@rehasport.pl 